\title{
EFFECT OF STORAGE TEMPERATURE, WRAPPING FILM AND STORAGE PERIOD ON SWEET CORN EAR BEHAVIOUR DURING STORAGE

\author{
Abou El-Yazied, A. ${ }^{1}$; I.I. El-Oksh'; Rawia E.I. El-Bassiony ${ }^{2}$ and
} Manal M. Attia ${ }^{2}$
}

1- Hort. Dept., Fac. Agric., Ain Shams Univ., Shoubra El-Kheima, Cairo, Egypt.

2- Postharvest and Handling of Vegetable Dept., Hort. Res. Inst., ARC, Giza, Egypt.

\begin{abstract}
The present study was undertaken at the postharvest laboratory, Horticulture Research Institute, Giza and development of horticulture, Ain Shams University. during 2002, 2003 and 2004 seasons to evaluate storability and maintain the physical and visual quality of sweet corn ears of Endeavor $F_{1}$ hybrid were picked at 25 day after silking (the optimum harvest stage) using cleaning stretch film and polyolefin film wrapping films at 0 and $5^{\circ} \mathrm{C}$ storage temperature at different storage periods. The main results showed that holding the ears at $5^{\circ} \mathrm{C}$ storage temperature increased the weight loss percent, denting, decay and reduced the visual quality values compared to holding at $0^{\circ} \mathrm{C}$. Carbon dioxide percent inside the package was higher when ears were stored at 5ㅇ compared to $0^{\circ} \mathrm{C}$ and when ears were wrapped with polyolefin film. Wrapping films reduced the weight loss percent of ears compared to unwrapping, the lowest values were by polyolefin film. In addition, wrapping with polyolefin film decreased kernel denting but the decay value was higher with polyolefin film compared to cleaning stretch film. Also, unwrapped ears had higher total sugar percent compared to ears wrapped with polyolefin film or cleaning stretch film. Cleaning stretch film, generally, gave best visual appearance during storage. Wrapping ears with polyolefin film maintained the sucrose percent higher than those of cleaning stretch film or check treatments. Sweet corn ears held at $0^{\circ} \mathrm{C}$ had higher percent of non-reducing sugars compared to $5^{\circ} \mathrm{C}$. Storing ears at $0^{\circ} \mathrm{C}$ maintained higher TSS compared to $5^{\circ} \mathrm{C}$. With prolonging the storage period, weight loss, decay, denting and discoloration for cut ends were increased. But, visual quality, TSS, total and non-reducing sugars were decreased.
\end{abstract}

Keywords: Sweet corn, Storage temperature, Storage period, Wrapping films, TSS, Sugars, Visual quality.

\section{INTRODUCTION}

Fresh sweet corn (Zea mays L. var. Saccharata) is a recently promising annual vegetable crop grown in Egypt. Sweet corn eating quality is associated with the consumer performance of kernel flavour, texture and aroma. Sweetness in sweet corn is closely related to kernel sucrose content and constituents most of what the average consumer perceives as flavour. The fresh sweet corn ear is a perishable food product prone to fast postharvest deterioration caused by kernel desiccation, loss of sweetness and moisture, husk discoloration and development of pathogens. Several techniques are used to preserve post-harvest quality. These techniques provide presumed optimal temperature, humidity and atmospheric modification. In this respect, Showalter (1967) found that ear weight loss for ears with no trimming were rapid and averaged nearly $22 \%$ after 6 days 
storage. Film packaging of husked ears provided protection against kernel denting and moisture loss equal to that of ears in the husk with shanks and flags removed. Moreover, Hardenburg (1971) stated that in a tight package all the free oxygen is used in a short time, respiration becomes an aerobic and alcohol and carbon dioxide are produced. This can be demonstrated easily by sealing sweet corn in a pliofilm bag. In a tight bag free oxygen is quickly used up but $\mathrm{CO}_{2}$ is still being produced. Injurious $\mathrm{CO}_{2}$ concentrations of $20 \%$ or higher are frequently found in tight packages at root temperature.

Ben-Yehoshua (1985), on seal-packaging in plastic film, stated that the conventional practice of waxing could be eliminated, since its function of preventing shrinkage and reducing weight loss would be increased 5 to 10 times by the film. Besides, it offers an attractive appearance and characteristics. Deak et al. (1987), on sweet corn, found that wrapping essentially eliminated moisture loss and resulted in elevated carbon dioxide and decreased oxygen concentrations within packages. These effects, together with refrigeration markedly reduced the changes associated with senescence and post-harvest deterioration, and hence resulted in at least a three-fold extension in shelf life. Risse and McDonald (1990), on a super sweet corn cultivar, found that film-wrapping maintained freshness and reduced moisture loss better than lack wrapping. Wrapping in shrink film resulted in lower $\mathrm{O}_{2}$ and higher $\mathrm{CO}_{2}$ concentrations with packages than wrapping with cleaning stretch film. Film wrapping in shrink film maintained total soluble solids content better than stretch-wrapping or no wrapping. Rodov et al. (2000) stated that retail packages of sweet corn (film-wrapped trays containing a pair of trimmed cobs) were stored at $2^{\circ} \mathrm{C}$ within additional plastic liners. The modified atmosphere, generated in these nested packages by corn respiration, complied with the recommended range 5-10 $\mathrm{kP} \mathrm{CO}_{2}$ and inhibited mould growth. Opening the liner after transfer to non-refrigerated conditions compensated for the respiration rise caused by elevated temperature maintained the desirable modified atmosphere range and prevented fermentation and off-flavour development.

Concerning storage temperature and storage period, Cherry (1974), on sweet corn, found that grain sucrose content decreased most rapidly with the conversion of starch during the first $24 \mathrm{~h}$ of post-harvest storage at $25^{\circ} \mathrm{C}$. Evenson and Boyer (1986) evaluated sweet corn for sensory quality and carbohydrate composition at harvest and after storage at $0^{\circ} \mathrm{C}$ or $10^{\circ} \mathrm{C}$ for two weeks. They found that total sugars (reducing sugars and sucrose) declined more quickly during storage at $10^{\circ} \mathrm{C}$ than at $0^{\circ} \mathrm{C}$ in all cultivars. In addition, Lee et al. (1987a) stated that at the temperature below $10^{\circ} \mathrm{C}$, contents of soluble solids and total sugars and flavour rate of sweet corn were not changed significantly, but at the temperature higher than $15^{\circ} \mathrm{C}$ they decreased as storage temperatures increased and duration extended. Moreover, Deak et al. (1987) mentioned that unwrapped de-husked white corn held at $20^{\circ} \mathrm{C}$ dried within 3-4 days and was unpalatable. Unwrapped yellow corn with husks intact stored at the same temperature dried within two weeks by showing little spoilage. Shrink-wrapped de-husked white ears showed visible signs of microbial growth within five days and yellow ears with 
husks showed deterioration within ten days at $20^{\circ} \mathrm{C}$. Kernels became discoloured, slimy and moldy in appearance. Shrink-wrapped white corn stored at $10^{\circ} \mathrm{C}$ developed a sweet off-odor and spoiled after two weeks storage. Shrink-wrapped yellow corn stored at $10^{\circ} \mathrm{C}$ remained in a good condition for four weeks. Unwrapped de-husked white corn lost its moisture at a much more rapid rate when stored at $20^{\circ} \mathrm{C}$ compared to storage at $10^{\circ} \mathrm{C}$.

Risse and McDonald (1990) found that the visual appearance was rated acceptable with both wrapped and non-wrapped corn up to 21 days of storage at $1^{\circ} \mathrm{C}$. Whereas, at $4^{\circ} \mathrm{C}$ the wrapped and unwrapped corn were rated acceptable after seven days, denting was observed on the unwrapped corn and to a lesser extent on the stretch wrapped corn. In general, wrapped corn appeared fresher; less dried and had less denting than non-wrapped. The amount of $\mathrm{CO}_{2}$ increased rapidly from $0 \%$ at time of packaging to $2-8 \%$ after 2 days, depending on the storage temperature, then stabilized. There was a positive relation between storage temperature and $\mathrm{CO}_{2}$ concentration. After most storage times, corn that was shrink wrapped had higher TSS content than either the non-wrapped corn or the corn that was stretchwrapped. Aharoni et al. (1996) mentioned that the packages affected the amount of $\mathrm{CO}_{2}$ and $\mathrm{O}_{2}$ measured within them during 12-day storage at $1^{\circ} \mathrm{C}$ and additional two days at $20^{\circ} \mathrm{C}$ as a shelf life. The amount of $\mathrm{CO}_{2}$ and $\mathrm{O}_{2}$ remained almost constant during 12 days storage. During the two days shelf life, the $\mathrm{CO}_{2}$ significantly increased to $15 \%$, while $\mathrm{O}_{2}$ significantly decreased to $3 \%$.

This study was, therefore, performed to determine the optimum storage temperature and packing materials of ears as well as delaying the deterioration of ears during storage.

\section{MATERIALS AND METHODS}

Seeds of sweet corn endeavor $F_{1}$ hybrid ( $s_{2}$ ) obtained from Asgrow Co. USA., was sown in 19 August during 2002 and 2003 at Qaha Experimental Station, Vegetables Research Department, Ministry of Agriculture.

Seeds of sweet corn were sown (Direct seed) in hills spaced $25 \mathrm{~cm}$ apart on rows of $70 \mathrm{~cm}$. The recommended culture practices of sweet corn production were followed. Ears were harvested on 18, 15 November in the first and second seasons, respectively, after 25 days from silkning in milky stage when the pollination silks are dried and the kernels are still immature. The husk leaves remain tigh and have a good green appearance. The kernels are plump and appear milky, and not doughy, when squeezed (the optimum harvest date for this hybrid, El-Seidy, 2006). Ears were picked and placed on Plastic crates and transported in a refrigerated truck at $\left(0^{\circ} \mathrm{C} \pm 2\right)$ immediately to the postharvest laboratory, Horticulture Research Institute, Giza. Within 1.5h, two wrapping films were used (cleaning stretch film and polyolefin film) manufactured by (Huckster packing supply Co. LTD. USA.). Their physical properties are summarized in Table (1).

Both polyolefin film and cleaning stretch film classified as a special material for food packing are using in food packing (both wrapping films were used according to requirements of EEC council directive 90/128/EEC, Barkai- 
Abou El-Yazied, A. et al.

Golden, 1990, and therefore they considered as environment-friendly packing films.

Table (1): physical properties of the two used films.

\begin{tabular}{|lcc|}
\hline Property & Polyolefin film & Cleaning stretch film \\
\hline Thickness (micron) & 20 & $0.90(90 \mathrm{GA})$ \\
Premmapelity : & & \\
Oxygen (ml/m 2 24h atm) & 11000 & 17000 \\
Carbon dioxide (ml $\left./ \mathrm{m}^{2} 24 \mathrm{~h} \mathrm{~atm}\right)$ & 7000 & 120000 \\
Color & Clear & Clear \\
Grade (using for...) & Food packing & Food packing \\
\hline
\end{tabular}

Uniform ears as uniform as possibole in ears diameter $(46 \mathrm{~mm})$ and length $(16 \mathrm{~cm})$ in two seasons of all harvesting were hydro-cooled to approximately $\left(0^{\circ} \mathrm{C}\right)$ with ice cold water after 3 hours from picking, then dried by air plower and kept overnight at $0^{\circ} \mathrm{C}$ with $95-98 \% \mathrm{RH}$ up to the following morning.

The shanks of ears were trimmed at least $1 \mathrm{~cm}$ from the ear base, the silk ends were cut to the end of ears and the outer leaves were removed, maintaining the leaves, which were attached to the ear with pulling a window of 2.5 to $4 \mathrm{~cm}$ wide of husks from the ears as practiced commercially. Then ears were placed on a foam tray (two ears/try) and over wrapped with cleaning stretch film (0.9 micron), low-density polyolefin film (20micron), or unwrapped (check treatment). Wrapped and unwrapped ears were weight, lapelled and placed in carton boxes (two trays/box) then stored at either $0^{\circ} \mathrm{C}$ and $95-98 \% \mathrm{RH}, 5^{\circ} \mathrm{C}$ and $95-98 \% \mathrm{RH}$ storage conditions. Four trays samples from the stored ears were taken, each with two ears, at 5, 10, 15 and 20 days from storage and subsequently transferred to $10^{\circ} \mathrm{C}$ (simulated retail display) for 24 hours to record the physical and chemical characters of ears to check the storability during the storage period and to record the following physical and chemical changes for each treatments:

A. Physical changes:

(1) Weight loss $\%$ was expressed as the percentage of loss from the initial weight according to the following equation:

Weight loss $\%=$ [Initial weight - weight of ears at sampling treatment / Initial weight of ears] $\times 100$

(2) Denting was determined as a score system of $1=$ None; 2 = Slight; $3=$ Moderate; 4 = moderately severe; 5 = severe.

(3) Decay were determined as a score system of $1=$ None; 2 = Slight; $3=$ Moderate; 4 = moderately severe; 5 = severe.

Decay incidence was evaluated separately for the flag leaves, cut ends and kernels, once mycelia appeared on each of them, and was expressed as a score system for the total amount of ears that were reated decayed.

(4) Visual quality general appearance was graded on a scale of 1-9, with 9 $=$ excellent quality, $7=$ good, $5=$ fair, $3=$ poor and $1=$ unusable (dry and brown flag leaves associated with fungal growth).

This scale depends on the morphological defects such as wilted husks, color changes of husk and kernels, and presence of physiological defects. 
B. Chemical changes:

(1) Total sugar and non-reducing sugars (sucrose) percent were determined colormetrically using spectrophotometer model 6305 UV/visible range with $520 \mathrm{~nm}$ wave length according to Somogyi (1952) and Nelson (1974).

(2) Dry matter one hundred gram of fresh kernels were weighed and then dried at $70^{\circ} \mathrm{C}$ until a constant weight was obtained, the dry matter was then calculated.

(3) Total soluble solids (TSS) were measured with a hand refractometer

C. Gases: Carbon dioxide inside package was determined in (0) time and during storage every 5 days until the end of storage period by using $\mathrm{Co}_{2}$ analyzer Mod. $902 \mathrm{D}$.

The experimental design: Completely randomised design in a factorial experiment with three factors (storage temperature, wrapping film and the storage period), in four replications, was used in this experiment. Statistical analysis was preformed according to Snedecor and Cochran (1989).

\section{RESULTS AND DISCUSSION}

\section{Physical characters}

\subsection{Weight loss \%}

Data presented in Table (2) showed that the weight loss percent of ears increased significantly when stored at $5^{\circ} \mathrm{C}$ compared to at $0^{\circ} \mathrm{C}$ in both seasons. As for wrapping film, weight loss percent of ears decreased significantly by using wrapping film and the most decreasing was by polyolefin film. This result was true for both seasons. Similar results were reported by Showalter (1967), Ben-Yehoshua (1985), Risse and McDonald (1990), Othieno et al. (1995) and Aharoni et al. (1996). They reported that using different kinds of over-wrapping film decreased the moisture and weight losses from the ears.

Concerning the storage period, the weight loss percent of ears increased with prolonging the storage period in both seasons. Regarding the interactions, the lowest significant values of weight loss during storage were observed for sweet corn ears wrapped with polyolefin film at any storage period, whereas the highest values of loss in weight were noticed in sweet corn ears stored up to 20 days at $5^{\circ} \mathrm{C}$ without wrapping (check treatment). These results were true in both seasons. This highest weight loss may be attributed to the highest transpiration as well as respiration rates under the higher temperature $\left(5^{\circ} \mathrm{C}\right)$ in the unwrapped sweet corn ears at any storage period compared to those held at $0^{\circ} \mathrm{C}$ and wrapped with polyolefin film.

\subsection{Denting}

Data in Table (3) indicated that denting of kernels increased with increasing the storage temperature, regardless of wrapping or storage period in the two seasons. Wrapping with polyolefin film decreased denting significantly compared to cleaning stretch film or check treatments, irrespective of storage temperature or period in both seasons. Regarding the storage period, denting increased with prolonging the storage period, regardless of wrapping or storage temperature. 
Abou El-Yazied, A. et al.

T2

1314 
J. Agric. Sci. Mansoura Univ., 32 (2), February, 2007

T3

1315 
Abou El-Yazied, A. et al.

As for interactions, the highest value of denting was recorded in unwrapped ears held at $5^{\circ} \mathrm{C}$ at 20 day storage period. While the lowest kernel denting values were recorded in ears wrapped with polyolefin film held at any storage period. These results were true in both seasons. The recorded denting values may due to highest loss of moisture content in check ears held at the higher temperature after 20 days of storage.

\subsection{Decay}

As shown in Table (4), the decay increased with increasing the storage temperature in the two studied seasons, regardless wrapping or storage period. Ears stored at $5^{\circ} \mathrm{C}$ temperature expressed higher decay values than the ears held at $0^{\circ} \mathrm{C}$ temperature. As for wrapping film, polyolefin film increased the value of decay significantly when compared with cleaning stretch film or check treatment. This was true in the two studied seasons, regardless storage temperature or period. Cleaning stretch film recorded, in general, the lowest value of decay. Similar results were reported by Aharoni et al. (1996). Regarding the storage period, the decay was increased with lengthening the storage period. As for the interaction, the highest value of decay was recorded, in general, in ears wrapped with polyolefin film in both studied seasons. However, the interaction among storage temperature, wrapping and storage period was significant in both seasons.

\subsection{Visual quality}

Data shown in Table (5) indicated that visual quality score of ears was higher during storage at $0^{\circ} \mathrm{C}$ compared to those held at $5^{\circ} \mathrm{C}$, irrespective of wrapping or storage period in both seasons. These results are in agreement with those of Risse and McDonald (1990). Wrapping the sweet corn ears with cleaning stretch film resulted, in general, in the best visual appearance compared to other wrapping treatments. The check (unwrapped ears) had the lowest visual quality scores in both seasons. These results were true regardless of storage temperature or period. Similar results were reported by Showalter (1967), Ben-Yehoshua (1985), Deak et al. (1987), Makino and Hirata (1997) and Rodov et al. (2000), who found that film packaging maintained freshness, reduced toughening, weight loss, microbial spoilage, moisture loss, senescence and denting, the parameters which affect positively the visual quality. Regarding the storage period, data showed that visual quality was decreased with extending the storage period. Concerning the interactions, sweet corn wrapped with cleaning stretch film showed the highest visual quality score during storage at $0^{\circ} \mathrm{C}$ up to 20 days compared to other combination treatments in both seasons, however, the significance was true for one season.

\section{5. $\mathrm{CO}_{2}$ percent inside the package}

Data presented in Table (6) showed that $\mathrm{CO}_{2}$ percent inside the packages was higher when ears were stored at $5^{\circ} \mathrm{C}$ compared to $0^{\circ} \mathrm{C}$, irrespective of wrapping film or storage period, in both seasons. Wrapping ears with polyolefin film or cleaning stretch film increased the $\mathrm{CO}_{2}$ percent inside the package compared with unwrapping check treatment. In addition, wrapping with polyolefin film gave significantly the highest $\mathrm{CO}_{2}$ values. 
J. Agric. Sci. Mansoura Univ., 32 (2), February, 2007 T4 
Abou El-Yazied, A. et al.

T5

1318 
J. Agric. Sci. Mansoura Univ., 32 (2), February, 2007

T6

1319 
Abou El-Yazied, A. et al.

Similar results were reported by Hardenburg (1971), Deak et al. (1987), Risse an McDonald (1990), Aharoni et al. (1996), Makino and Hirata (1997) and Rodov et al. (2000), who found that using different kinds of films in packaging sweet corn generated modified atmosphere inside the package by elevating $\mathrm{CO}_{2}$ amount and decreasing the amount of free oxygen. As for storage period, $\mathrm{CO}_{2}$ percent in the package increased during storage by extending the storage period where the highest percent of $\mathrm{CO}_{2}$ was found after $20+1$ days. Concerning the first order interactions, the highest $\mathrm{CO}_{2}$ percent inside package during storage was produced by sweet corn ears wrapped with polyolefin film at $5^{\circ} \mathrm{C}$, prolonging the storage period at $5^{\circ} \mathrm{C}$ up to $20+1$ days or wrapping with polyolefin film up to 20 days. For interaction among temperature, wrapping film and storage period, the sweet corn ears wrapped with polyolefin film after $20+1$ days storage at $5^{\circ} \mathrm{C}$ produced the highest percent of $\mathrm{CO}_{2}$ inside the package. These results were true in both seasons.

\section{Chemical analyses}

\subsection{Total sugar percent}

Data presented in Table (7) showed that there was no significant difference in total sugar percent of sweet corn ears stored at 0 and $5^{\circ} \mathrm{C}$ in both seasons. These results were true regardless of wrapping film or storage period. As respecting the wrapping film, the unwrapped ears had the highest value of total sugar percent compared to other wrapping treatments, whereas those wrapped with cleaning stretch film had the lowest value. As for storage period, it was noticed that total sugar percent decreased with prolonging the storage period in both seasons. These results were true irrespective of storage temperature. Similar results were reported by Winter et al. (1955), Evenson and Boyer (1986), Lee et al. (1987b), and Olsen et al. (1990), who found that total sugar concentration was affected by storage time. Concerning the interaction, the combination between storage temperatures and wrapping film showed that check (unwrapped ears) held at $5^{\circ} \mathrm{C}$ contained the highest value of total sugars, in the two studied seasons. The interaction between storage period and temperature was not significant in the two studied seasons. The interaction among temperature, film and storage period showed that the highest value of total sugars after $20+1$ days were found with unwrapped ears (check) stored at $5^{\circ} \mathrm{C}$.

\subsection{Non-reducing sugars (sucrose) percent}

Data shown in Table (8) indicated that sweet corn ears held at $0^{\circ} \mathrm{C}$ had higher percent of non-reducing sugars in both tested seasons. Concerning the wrapping film, data showed that polyolefin film increased the value of non-reducing sugars in kernels of sweet corn ears in both seasons, this was true irrespective of storage temperature or period.

Concerning the storage period, the sucrose percent decreased significantly with lengthening the storage period, the lowest values were detected after $20+1$ days. This was true during both seasons, regardless of wrapping film or storage temperature. These results are in agreement with those reported by Cherry (1974), Garwood et al. (1976), Carey et al. (1982), Evenson and Boyer (1986) and Olsen et al. (1990), who found that sucrose content decreased rapidly during storage. 
J. Agric. Sci. Mansoura Univ., 32 (2), February, 2007 T7 
Abou El-Yazied, A. et al.

T8

1322 
The interactions among storage temperature, wrapping film and storage period, were not statistically significant in both seasons, with one exceptional, i.e., the interaction between wrapping film and storage period. Wrapping in polyolefin film caused generally highest values of non-reducing sugars at any storage period. Such effect was significant in the first season only.

\subsection{Total soluble solids (TSS) percent}

Data presented in Table (9) showed that TSS \% was higher in kernels held at $0^{\circ} \mathrm{C}$ compared to those stored at $5^{\circ} \mathrm{C}$ during storage, irrespective of wrapping film or storage period. Wrapping with cleaning stretch film or polyolefin film decreased kernel's TSS \% compared to check treatment. But the difference was not significant in the second season. Concerning the storage period, TSS \% was gradually decreased by prolonging the storage period. The lowest values were recorded at $20+1$ days from storage, regardless of wrapping film or storage temperature. Similar results were reported by Lee et al. (1987b) and Risse and McDonald (1990). Regarding the interactions, the lowest TSS \% was recorded in kernels wrapped with either cleaning stretch film or polyolefin film after $20+1$ days storage at $5^{\circ} \mathrm{C}$, in both seasons.

\subsection{Dry matter percent}

Data in Table (10) showed that no significant difference was found in dry matter percent in kernels kept at 0 and $5^{\circ} \mathrm{C}$. On the other hand, kernels of check treatment contained the highest dry matter percent followed, by polyolefin film then cleaning stretch film. This was true, regardless of storage temperature or period. In addition, the dry matter \% increased with increasing the storage period up to $15+1$ days in both studied seasons. The combination between the wrapping film and storage period was significant in both seasons.

The obtained results indicated that kernels of unwrapped ears had the highest value of dry matter after $20+1$ days from storage followed by those wrapped in polyolefin film then cleaning stretch film.

It could be concluded from the previously mentioned results that the total sugars and sucrose were not significantly affected by storage temperature. This might be due to the high initial sugar content in the sweet corn kernels and the loss in sugar content was insignificantly observed. The unwrapped ears (check treatment) were the highest in total sugar values comparing to wrapping films. This result might be due to the high and rapid moisture loss in the kernels of check treatment compared to wrapped ones. These results agree with those of Showalter (1967), Hardenburg (1971), Deak et al (1987), Risse and McDonald (1990), Othieno et al. (1995), Aharoni et al. (1996), Makino and Hirata (1997) and Aharoni et al. (1997). On the Contrary, polyolefin film and cleaning stretch film maintained higher sucrose percent compared to check treatment, this may be due to that wrapping film reduced the loss of water and reduced the gas exchangeable creating a modified atmosphere which decrease the rate of respiration and hence the loss of sucrose during storage. Similar results were reported by Hardenburg (1971), Deak et al. (1987), Risse and McDonald (1990) and Aharoni et al. (1996). 
Abou El-Yazied, A. et al.

T9

1324 
J. Agric. Sci. Mansoura Univ., 32 (2), February, 2007

$\mathrm{T} 10$ 
Concerning the storage period, total and non reducing sugars were decreased by lengthening the storage period. These results are in agreement with those of Winter et al (1955), Cherry (1974), Carey et al. (1982), Evenson and Boyer (1986), Lee et al. (1987b) and Olsen et al. (1990). This might be attributed to the consumption of sugars in respiration and/or the conversion of sugars to starch. TSS \% was higher in kernel stored at $0^{\circ} \mathrm{C}$ compared to those held at $5^{\circ} \mathrm{C}$. This result agrees with Deak et al. (1987). Kernels of unwrapped ears (check treatment) contained higher dry matter percent than those of wrapped ones. This may be due to rapid loss of water from check treatment comparing to the wrapped ears. Extending the storage period increase TSS and dry matter percent, which may be due to the loss of water of kernels, consequently increased the concentration of these parameters and this agree with Cherry (1974), Garwood et al. (1976), Evenson and Bayer (1986), Risse and McDonald (1990) and Aharoni et al. (1996).

It could be concluded that weight loss percent, denting, decay and the $\mathrm{CO}_{2}$ percent increased by increasing the storage temperature $\left(5^{\circ} \mathrm{C}\right)$ and this might be attributed to that the high temperature accelerates the biochemical processes such as respiration rate which increased the content of $\mathrm{CO}_{2}$ inside package. The high temperature $\left(5^{\circ} \mathrm{C}\right)$ also increases the loss of water, which cause denting and activates the pathogens, which increase the deterioration and decay, therefore, the optimum storage temperature for sweet corn is $\left(0^{\circ} \mathrm{C}\right)$. It could be also concluded that wrapping films reduced the weight loss percent, denting and maintained quality through generating a modified atmosphere around ears and elevated $\mathrm{CO}_{2}$ percent and reduced free oxygen, which reduce the rate of respiration and maintain quality by delay loss of sucrose content and maintain appearance of husks. In addition, wrapping film reduces the gas exchange and preserves a saturated modified atmosphere of water vapour, which reduces the moisture loss and keeps out the freshness.

\section{REFERENCES}

Aharoni, Y., D.G. Richardson and M.E. Soltveit (1997). New higher water permeable films for modified atmosphere packing of fruit and vegetables. Prolonged MAP storage of sweet corn. Seventh International Controlled Atmosphere Research Conference, CA. 97 Proc. Vol. (4) Vegetables and Ornamentals, Davis, California, USA, 1318. (C.A. CAB Abstracts 2000/03).

Aharoni, Y.; A. Copel, M. Gill and E. Fallik (1996). Polyolefin stretch films maintain the quality of sweet corn during storage and shelf life. Postharvest Biol. Technol. 7: 171-176.

Barkai-Golden, R. (1990). Postharvest disease suppression by atmospheric modification. In : calderon and R. Barkai-Golden (Editors), food preservation by modified atmospheres. CRC press, Boca Raton, Fla., pp 238-264.

Ben-Yehoshua, S. (1985). Individual seal-packaging of fruit and vegetables in plastic film. A new postharvest technique. HortScience, 20 (1): 32-36. 
Carey, E.E.; A.M. Rhodes and D.B. Dickinson (1982). Postharvest levels of sugars in sugary enhance (suse) and Sugary (suSe) maize. HortScience, 17 (2): 241-242.

Cherry, J.H. (1974). Control of sucrose conversion to starch in sweet corn after harvest. Bulletin. The Royal Society of New-Zealand No. 12: 812817. (c.a. CAB Abstracts 2000/03).

Deak, T., E.K. Heaton, Y.C. Hung and L.R. Beuchat (1987). Extending the shelf life of fresh sweet corn by shrink-wrapping, refrigeration and irradiation. J. Food Sci., 25 (6): 1625-1631.

El-Seidy,M.M. (2006). Effect of some pre and post harvest treatments on quality of sweet corn. Ph.D. Thesis, Faculty of Agriculture, Ain Shams Univ. Cairo, Egypt. 116p.

Evenson, K.B. and C.D. Boyer (1986). Carbohydrate composition and sensory quality of fresh and stored sweet corn. J. Amer. Soc. Hort. Sci., 111 (5): 734-738.

Garwood, D.L., F.J. Mcardle, S.F. Vanderslice and J.C. Shannon (1976). Postharvest carbohydrate transformation and processed quality of high sugars maize genotypes. J. Amer. Soc. Hort. Sci., 101 (4): 400-404.

Hardenburg, R.E. (1971). Effect of in-package environment on keeping quality of fruits and vegetables. HortScience, 6 (3): 198-201.

Lee, S.S., S.K. Lee and D.Y. Kim (1987a). Quality of sweet corn stored at different temperatures and duration. Korean J. of Crop Sci., 32 (2): 137-143.

Lee, S.S., T.J. Kim and J.S. Park (1987 b). Sugars, soluble solids and flavor as influenced by maturity of sweet corn. Korean J. Crop Sci., Vol. 32 (1): 86-92.

Makino, Y. and T. Hirata (1997). Modified atmosphere packaging of fresh produce with a biodegradable laminate of chitosan-cellulose and polycarprolactone. Post-harvest Biol. \& Tech., 10 (3): 247-254.

Nelson, N. (1974). A photometric adaptation of the Somogyi methods for determination of glucose. J. Biol. Chem., 195: 19-23.

Olsen, J.K., J.E. Giles and R.A. Jardan (1990). Post-harvest carbohydrate changes sensory quality of three sweet corn cultivars. Scentia Horticulture, 44: 179-189.

Othieno, J.K., A.K. Thompson, J. de Baemdemaeker, B. McKenna, M. Jansses, A. Thompson, F. Artes-Calero, E. Hohn and Z. Somogyi (1995). Modified atmosphere packaging of sweet corn. Cost 94. The postharvest treatment of fruit and vegetables: Systems and operation for post-harvest quality. Proc. of Workshop, Leuven, Belgium, 14-15 Sept., 1993. 1995, 247-254. (C.A. CAB Abstracts, 2000/03).

Risse, L.A. and R.E. McDonald (1990). Quality of super-sweet corn film over wrapped in trays. HortScience, 25 (3): 322-324.

Rodov, V., A. Copel, N. Aharoni, Y. Aharoni, A. Wiseblum, B. Horev and Y. Vinokur (2000). Nested modified-atmosphere packages maintain quality of trimmed sweet corn during cold storage and the shelf life period. Postharvest Biol. \& Tech., 18: 259-266.

Showalter, R.K. (1967). Sweet corn shelf-life as affected by trimming and packaging. J. Amer. Soc. Hort. Sci., 91: 881-884. 


\section{Abou El-Yazied, A. et al.}

Snedecor, G.W. and W.G. Cochran (1989). Statistical Methods. $8^{\text {th }}$ Ed. lowa State Univ. Press, Ames, lowa, USA.

Somogyi, M. (1952). Noted on sugar determination. J. Biol. Chem., 195: 1923.

Winter, J.D., R.E. Nylund and A.F. Legun (1955). Relation of sugars to flavor of sweet corn after harvest. Proc. Amer. Soc. Hort. Sci., 87: 393-396.

$$
\begin{aligned}
& \text { تأثير درجة حرارة التخزين، نوع الغلاف و طول مدة التخزين على مواصفات كيزان }
\end{aligned}
$$

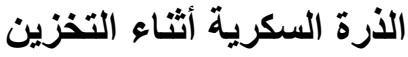

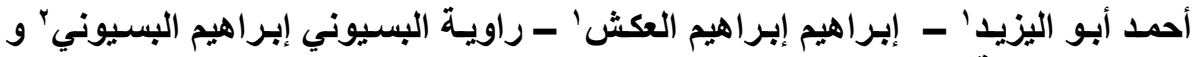

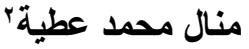

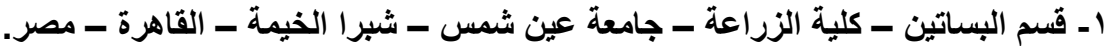

$$
\begin{aligned}
& \text { r ـ قسم بحوث تداول الخضر - معهد بحوث البساتين - مركز البحوث الزئ الزراعية - جيزة - مصر. } \\
& \text { أجريت هذه الدراسة في قسم تداول الخضر بمعهد بحوث البساتين وقسم البساتين بكلية الزراعة جامعة بكانة }
\end{aligned}
$$

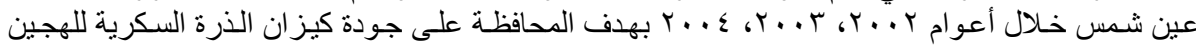

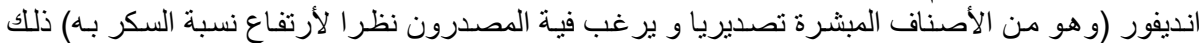

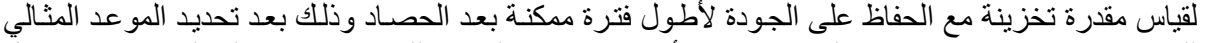

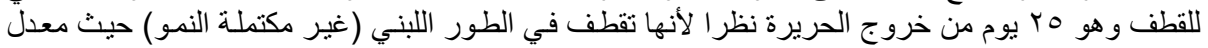

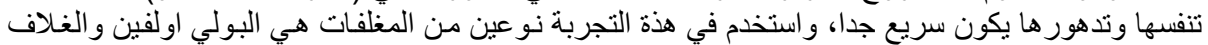

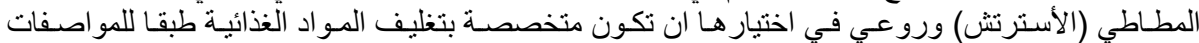

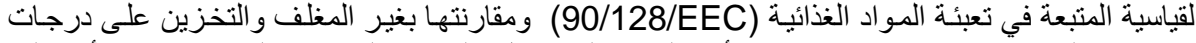

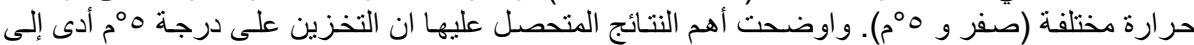

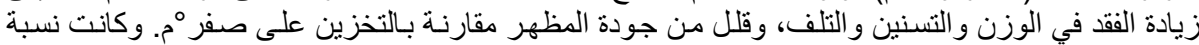

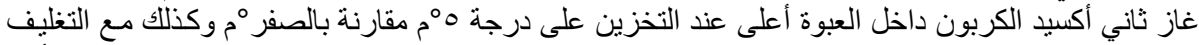

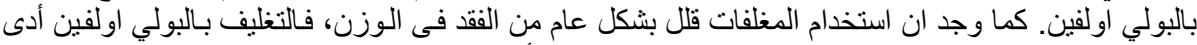

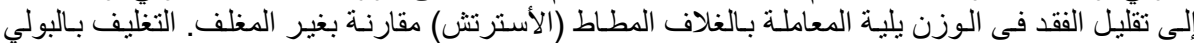

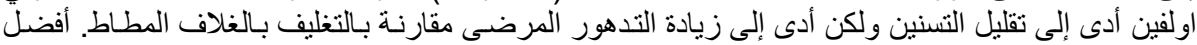

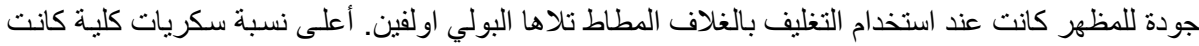

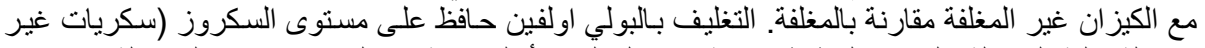

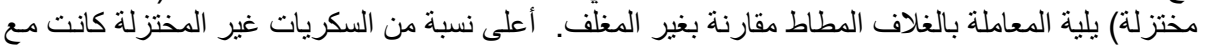

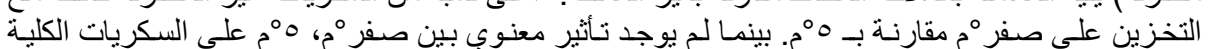

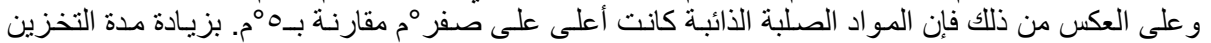

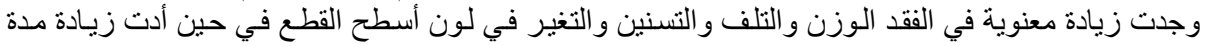

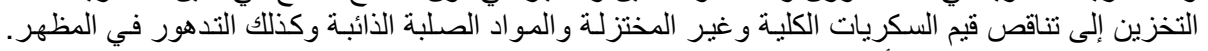

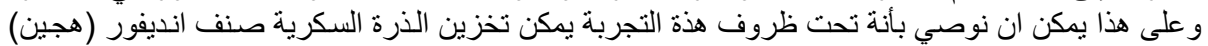

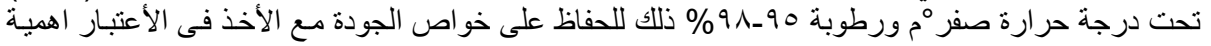

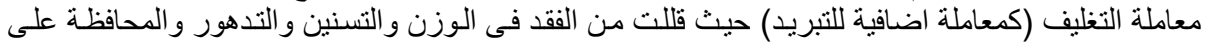

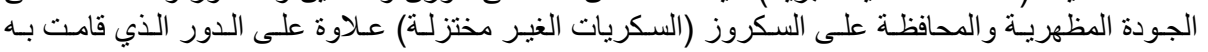

$$
\begin{aligned}
& \text { المغلفات كمعاملة اخرى اضافية للتخزين المبرد كنوع من انواع الجو الهور الهوائي المعدل (MAP) لتقليل التدهور }
\end{aligned}
$$

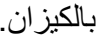


J. Agric. Sci. Mansoura Univ., 32 (2), February, 2007 
J. Agric. Sci. Mansoura Univ., 32 (2): 1309 - 1328, 2007

Table (2): Effect of storage temperature (at $\mathrm{RH} \%=95-98 \%$ ), wrapping film and storage period on weight loss\% of Endeavor F1 sweet corn hybrid.

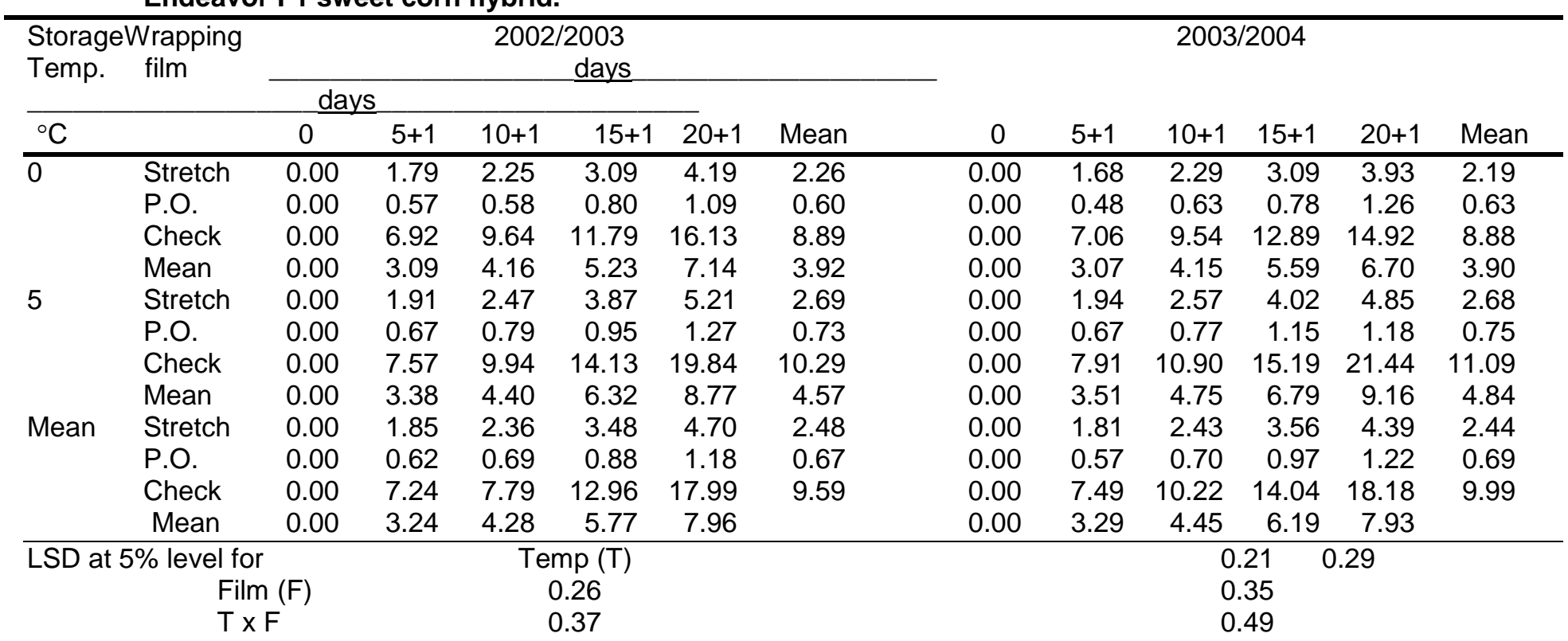


J. Agric. Sci. Mansoura Univ., 32 (2), February, 2007

$\begin{array}{ll}\text { Storage period (S) } & 0.33 \\ \text { TxS } & 0.47 \\ \text { FxS } & 0.58 \\ \text { Tx F X S } & 0.82\end{array}$

0.58

0.82
0.45
0.64
0.79
1.12


Abou El-Yazied, A. et al.

Table (3): Effect of storage temperature (at $\mathrm{RH} \%=95-98 \%$ ), wrapping film and storage period on denting (score values) of Endeavor F1 sweet corn hybrid.

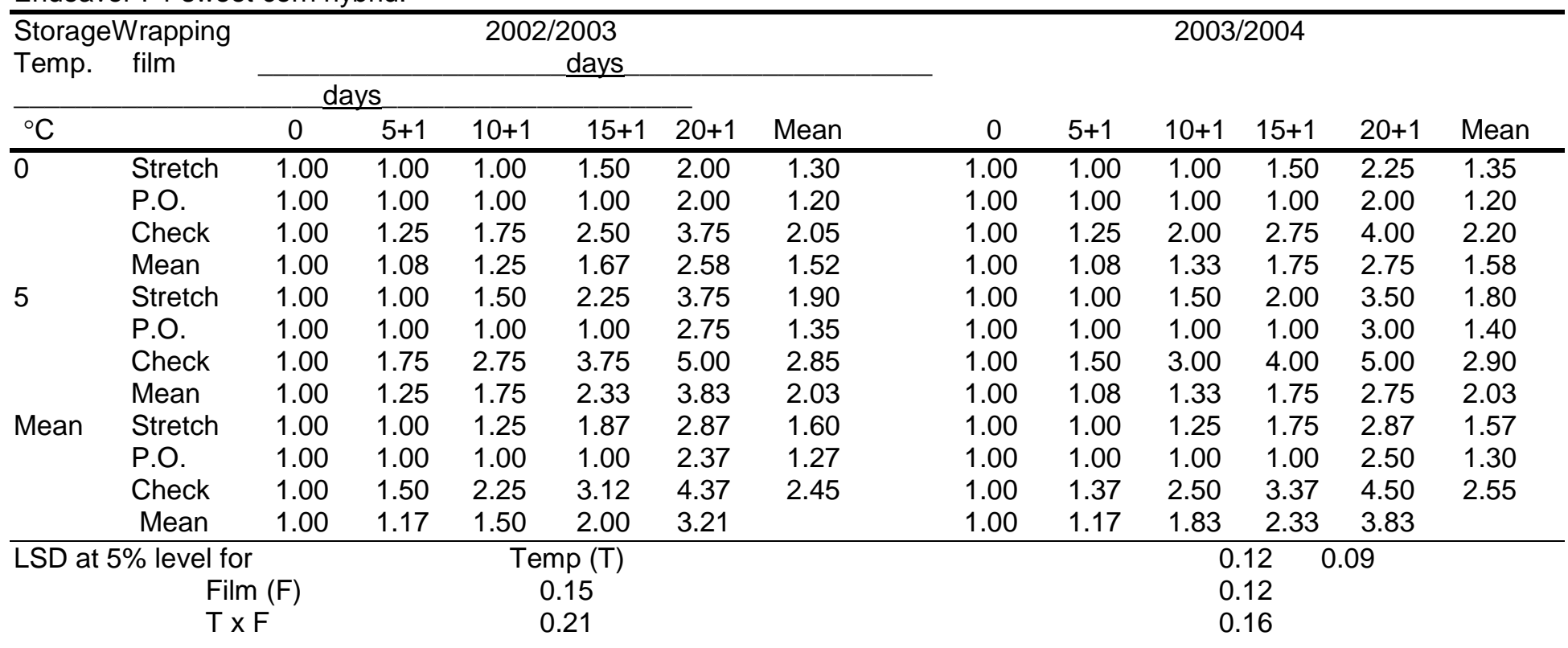

1332 
J. Agric. Sci. Mansoura Univ., 32 (2), February, 2007

$\begin{array}{lll}\text { Storage period (S) } & 0.19 & 0.15 \\ \text { T X S } & 0.27 & 0.21 \\ \text { F X S } & 0.33 & 0.26 \\ \text { T X F X S } & \text { NS } & 0.37\end{array}$

Denting score: 1: none, 2: slight, 3: moderate, 4: moderately severe, 5: severe.

P.O. = polyolefin film

Table (4): Effect of storage temperature (at $\mathrm{RH} \%=95-98 \%$ ), wrapping film and storage period on decay (score values) of Endeavor F1 sweet corn hybrid.

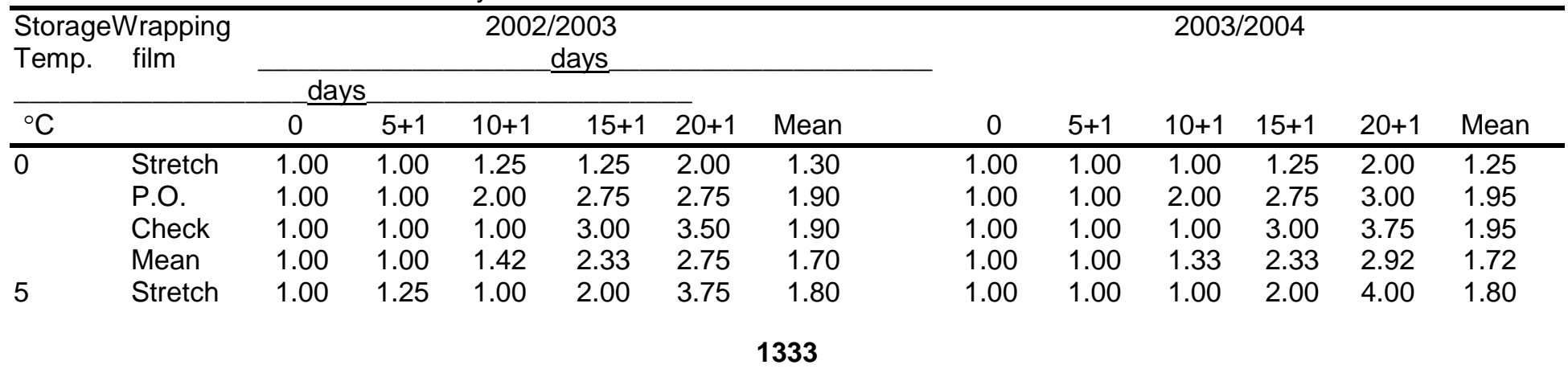


Abou El-Yazied, A. et al.

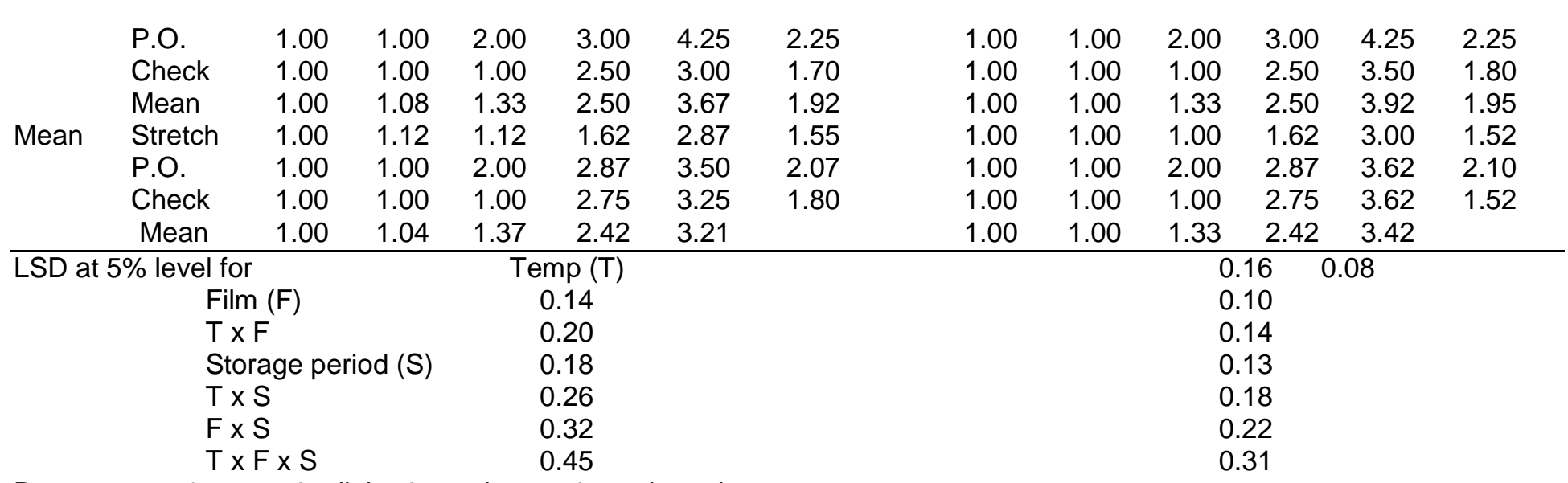

Decay score: 1: none, 2: slight, 3: moderate, 4: moderately sever, 5: severe.

P.O. = polyolefin film

Table (5): Effect of storage temperature (at $\mathrm{RH} \%=95-98 \%$ ), wrapping film and storage period on visual quality (score values) of Endeavor F1 sweet corn hybrid. 
J. Agric. Sci. Mansoura Univ., 32 (2), February, 2007

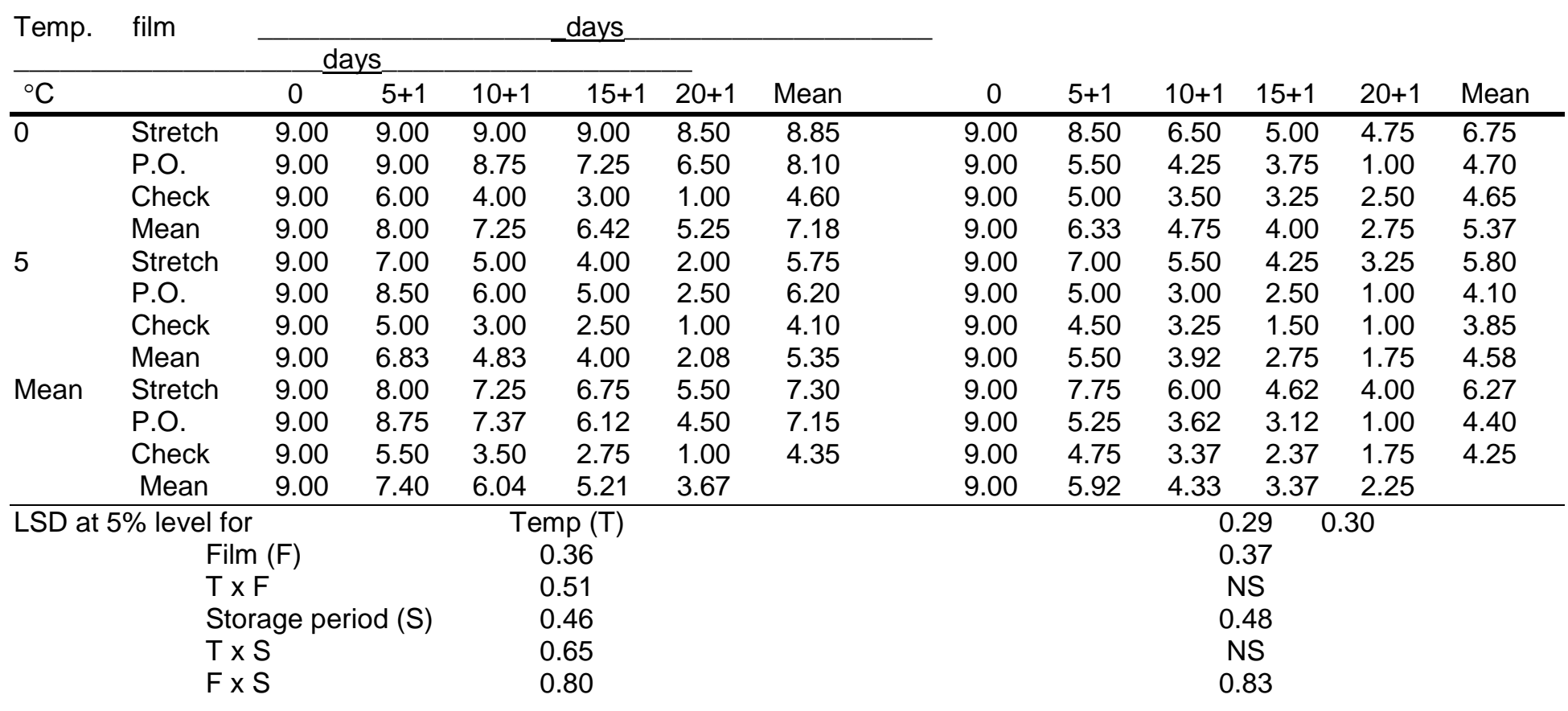

1335 
Abou El-Yazied, A. et al.

$\mathrm{T} \times \mathrm{F} \times \mathrm{S}$

1.13

NS

Visual quality score: 9: excellent, 7: good, 5: fair, 3: poor and 1: unsolable.

P.O. = polyolefin film

Table (6): Effect of storage temperature (at $\mathrm{RH} \%=95-98 \%$ ), wrapping film and storage period on $\mathrm{CO}_{2} \%$ inside package of Endeavor F1 sweet corn hybrid.

\begin{tabular}{|c|c|c|c|c|c|c|c|c|c|c|c|c|c|}
\hline \multirow{2}{*}{\multicolumn{2}{|c|}{$\begin{array}{l}\text { StorageWrapping } \\
\text { Temp. film }\end{array}$}} & \multicolumn{6}{|c|}{$\begin{array}{c}2002 / 2003 \\
\text { days }\end{array}$} & \multicolumn{6}{|c|}{$2003 / 2004$} \\
\hline & & \multicolumn{6}{|c|}{ days } & \multirow[b]{2}{*}{0} & \multirow[b]{2}{*}{$5+1$} & \multirow[b]{2}{*}{$10+1$} & \multirow[b]{2}{*}{$15+1$} & \multirow[b]{2}{*}{$20+1$} & \multirow[b]{2}{*}{ Mean } \\
\hline$\circ$ & & 0 & $5+1$ & $10+1$ & $15+1$ & $20+1$ & Mean & & & & & & \\
\hline \multirow[t]{4}{*}{0} & Stretch & 0.03 & 3.90 & 4.52 & 4.57 & 4.85 & 3.58 & 0.03 & 3.85 & 4.11 & 4.32 & 4.50 & 3.36 \\
\hline & P.O. & 0.03 & 6.70 & 6.80 & 8.57 & 9.05 & 6.23 & 0.03 & 6.45 & 7.20 & 8.45 & 8.90 & 6.21 \\
\hline & Check & 0.03 & 0.03 & 0.03 & 0.03 & 0.03 & 0.03 & 0.03 & 0.03 & 0.03 & 0.03 & 0.03 & 0.03 \\
\hline & Mean & 0.03 & 3.54 & 3.78 & 4.39 & 4.64 & 3.28 & 0.03 & 3.44 & 3.78 & 4.27 & 4.48 & 3.20 \\
\hline \multirow[t]{4}{*}{5} & Stretch & 0.03 & 4.01 & 4.50 & 4.87 & 5.00 & 3.68 & 0.03 & 3.95 & 4.10 & 4.52 & 4.70 & 3.46 \\
\hline & P.O. & 0.03 & 9.15 & 9.22 & 9.47 & 10.35 & 7.65 & 0.03 & 8.12 & 9.97 & 10.39 & 10.57 & 7.82 \\
\hline & Check & 0.03 & 0.03 & 0.03 & 0.03 & 0.03 & 0.03 & 0.03 & 0.03 & 0.03 & 0.03 & 0.03 & 0.03 \\
\hline & Mean & 0.03 & 4.39 & 4.58 & 4.79 & 5.13 & 3.79 & 0.03 & 4.03 & 4.70 & 4.98 & 5.10 & 3.77 \\
\hline
\end{tabular}

1336 
J. Agric. Sci. Mansoura Univ., 32 (2), February, 2007

\begin{tabular}{|c|c|c|c|c|c|c|c|c|c|c|c|c|c|}
\hline Mean & $\begin{array}{l}\text { Stretch } \\
\text { P.O. } \\
\text { Check } \\
\text { Mean }\end{array}$ & $\begin{array}{l}0.03 \\
0.03 \\
0.03 \\
0.03\end{array}$ & $\begin{array}{l}3.96 \\
7.92 \\
0.03 \\
3.97\end{array}$ & $\begin{array}{l}4.51 \\
8.01 \\
0.03 \\
4.18\end{array}$ & $\begin{array}{l}4.72 \\
9.02 \\
0.03 \\
4.59\end{array}$ & $\begin{array}{l}4.92 \\
9.70 \\
0.03 \\
4.88\end{array}$ & $\begin{array}{l}3.63 \\
6.94 \\
0.03\end{array}$ & $\begin{array}{l}0.03 \\
0.03 \\
0.03 \\
0.03\end{array}$ & $\begin{array}{l}3.90 \\
7.28 \\
0.03 \\
3.74\end{array}$ & $\begin{array}{l}4.10 \\
8.58 \\
0.03 \\
4.24\end{array}$ & $\begin{array}{l}4.42 \\
9.42 \\
0.03 \\
4.62\end{array}$ & $\begin{array}{l}4.60 \\
9.73 \\
0.03 \\
4.79\end{array}$ & $\begin{array}{l}3.41 \\
7.01 \\
0.03\end{array}$ \\
\hline LSD at & $\begin{array}{r}\% \text { level } \mathrm{f} \\
\mathrm{Fi} \\
\mathrm{T} \\
\mathrm{St} \\
\mathrm{T} \\
\mathrm{F} \\
\mathrm{T}\end{array}$ & $\begin{array}{l}(F) \\
\text { a } \\
\text { a }\end{array}$ & $d(S)$ & & $\begin{array}{l}p(T) \\
21 \\
30 \\
27 \\
39 \\
48 \\
67\end{array}$ & & & & & & & 3 & \\
\hline
\end{tabular}

P.O. = polyolefin film

Table (7): Effect of storage temperature (at RH \%= 95-98\%), wrapping film and storage period on total sugars \% (g/100 g fresh weight) of Endeavor F1 sweet corn hybrid.

\begin{tabular}{lcc}
\hline $\begin{array}{l}\text { StorageWrapping } \\
\text { Temp. film }\end{array}$ & $\begin{array}{c}2002 / 2003 \\
\text { days }\end{array}$ & 2003/2004 \\
\cline { 2 - 3 } & & days \\
\hline
\end{tabular}

1337 
Abou El-Yazied, A. et al.

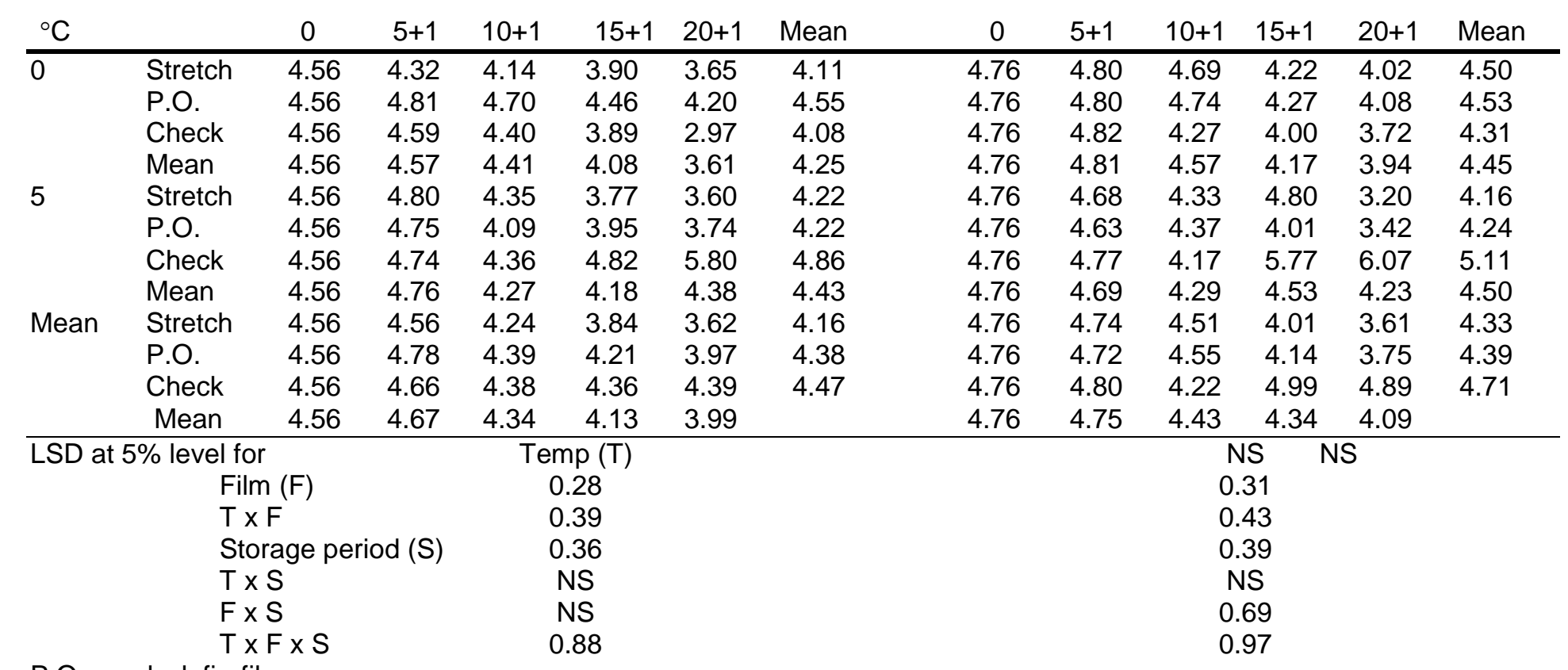


J. Agric. Sci. Mansoura Univ., 32 (2), February, 2007

Table (8): Effect of storage temperature (at $\mathrm{RH} \%=95-98 \%$ ), wrapping film and storage period on non-reducing sugars $\%$ (sucrose) (g/100 g fresh weight) of Endeavor F1 sweet corn hybrid.

\begin{tabular}{|c|c|c|c|c|c|c|c|c|c|c|c|c|c|}
\hline \multirow{2}{*}{\multicolumn{2}{|c|}{$\begin{array}{l}\text { StorageWrapping } \\
\text { Temp. film }\end{array}$}} & \multicolumn{6}{|c|}{$\begin{array}{c}2002 / 2003 \\
\text { days }\end{array}$} & \multicolumn{6}{|c|}{$2003 / 2004$} \\
\hline & & \multicolumn{6}{|c|}{ days } & \multirow[b]{2}{*}{0} & \multirow[b]{2}{*}{$5+1$} & \multirow[b]{2}{*}{$10+1$} & \multirow[b]{2}{*}{$15+1$} & \multirow[b]{2}{*}{$20+1$} & \multirow[b]{2}{*}{ Mean } \\
\hline${ }^{\circ} \mathrm{C}$ & & 0 & $5+1$ & $10+1$ & $15+1$ & $20+1$ & Mean & & & & & & \\
\hline \multirow[t]{4}{*}{$\overline{0}$} & Stretch & 3.85 & 3.59 & 3.11 & 2.79 & 1.99 & 3.07 & 3.93 & 3.60 & 3.46 & 3.17 & 2.01 & 3.23 \\
\hline & P.O. & 3.85 & 3.67 & 3.41 & 3.16 & 2.54 & 3.32 & 3.93 & 3.79 & 3.56 & 3.01 & 2.66 & 3.39 \\
\hline & Check & 3.85 & 3.38 & 2.86 & 2.42 & 1.83 & 2.87 & 3.93 & 3.43 & 3.36 & 3.02 & 1.61 & 3.07 \\
\hline & Mean & 3.85 & 3.55 & 3.12 & 2.79 & 2.12 & 3.09 & 3.93 & 3.61 & 3.46 & 3.07 & 2.09 & 3.23 \\
\hline \multirow[t]{4}{*}{5} & Stretch & 3.85 & 3.67 & 3.04 & 2.88 & 2.34 & 3.16 & 3.93 & 3.65 & 3.23 & 2.83 & 2.25 & 3.19 \\
\hline & P.O. & 3.85 & 3.71 & 3.34 & 2.80 & 2.42 & 3.22 & 3.93 & 3.74 & 3.54 & 2.83 & 2.57 & 3.32 \\
\hline & Check & 3.85 & 3.65 & 2.20 & 1.97 & 1.82 & 2.69 & 3.93 & 3.41 & 2.83 & 2.32 & 1.88 & 2.87 \\
\hline & Mean & 3.85 & 3.67 & 2.86 & 2.55 & 2.19 & 3.03 & 3.93 & 3.60 & 3.20 & 2.66 & 2.23 & 3.12 \\
\hline \multirow[t]{4}{*}{ Mean } & Stretch & 3.85 & 3.63 & 3.07 & 2.83 & 2.17 & 3.11 & 3.93 & 3.62 & 3.34 & 3.00 & 2.13 & 3.20 \\
\hline & P.O. & 3.85 & 3.69 & 3.37 & 2.98 & 2.48 & 3.27 & 3.93 & 3.76 & 3.55 & 2.92 & 2.61 & 3.35 \\
\hline & Check & 3.85 & 3.51 & 2.53 & 2.19 & 1.83 & 2.78 & 3.93 & 3.42 & 3.09 & 2.67 & 1.74 & 2.97 \\
\hline & Mean & 3.85 & 3.61 & 2.99 & 2.67 & 2.16 & & 3.93 & 3.60 & 3.33 & 2.86 & 2.16 & \\
\hline
\end{tabular}


Abou El-Yazied, A. et al.

LSD at $5 \%$ level for

$\begin{array}{lc}\text { Film }(F) & 0.14 \\ \text { TxF } & N S \\ \text { Storage period (S) } & 0.18 \\ \text { TxS } & N S \\ \text { F } \times S & 0.31 \\ T \times F \times S & N S\end{array}$

NS NS

0.17

NS

0.22

NS

NS

$\mathrm{T} \times \mathrm{F} \times \mathrm{S}$

NS

NS

P.O. = polyolefin film

Table (9): Effect of storage temperature (at $\mathrm{RH} \%=95-98 \%$ ), wrapping film and storage period on TSS \% of Endeavor F1 sweet corn hybrid.

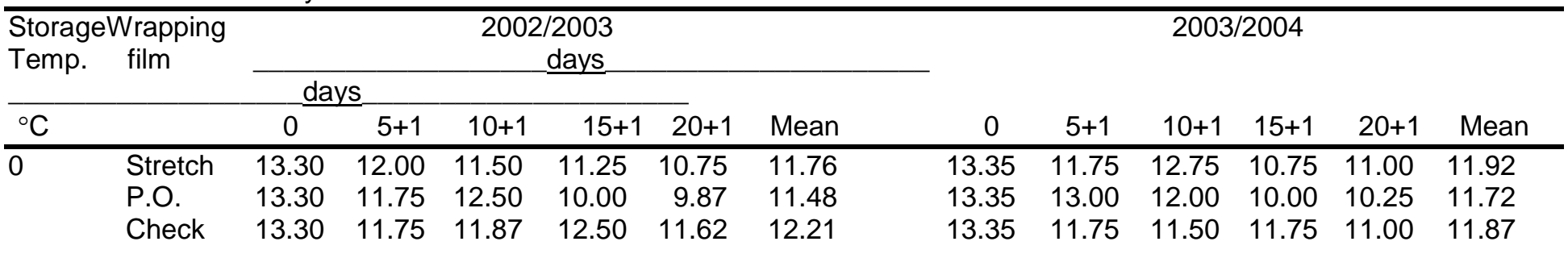

1340 
J. Agric. Sci. Mansoura Univ., 32 (2), February, 2007

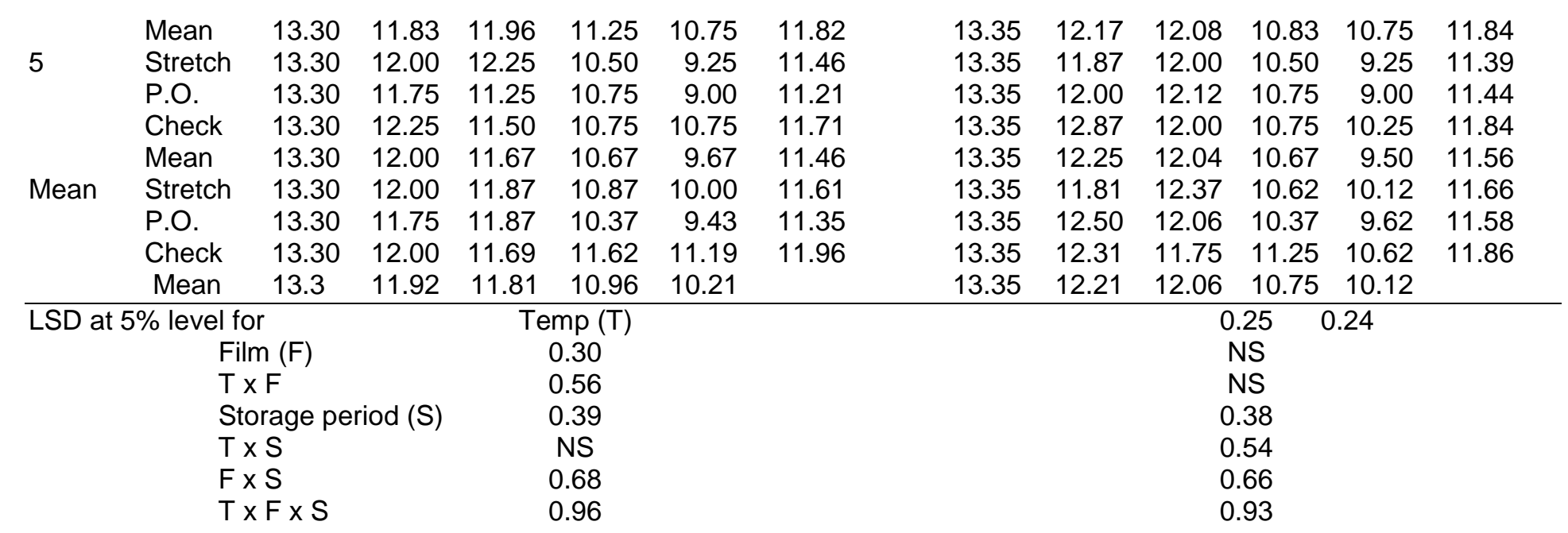

P.O. = polyolefin film 
Abou El-Yazied, A. et al.

Table (10): Effect of storage temperature (at RH \%= 95-98\%), wrapping film and storage period on dry matter \% of Endeavor F1 sweet corn hybrid.

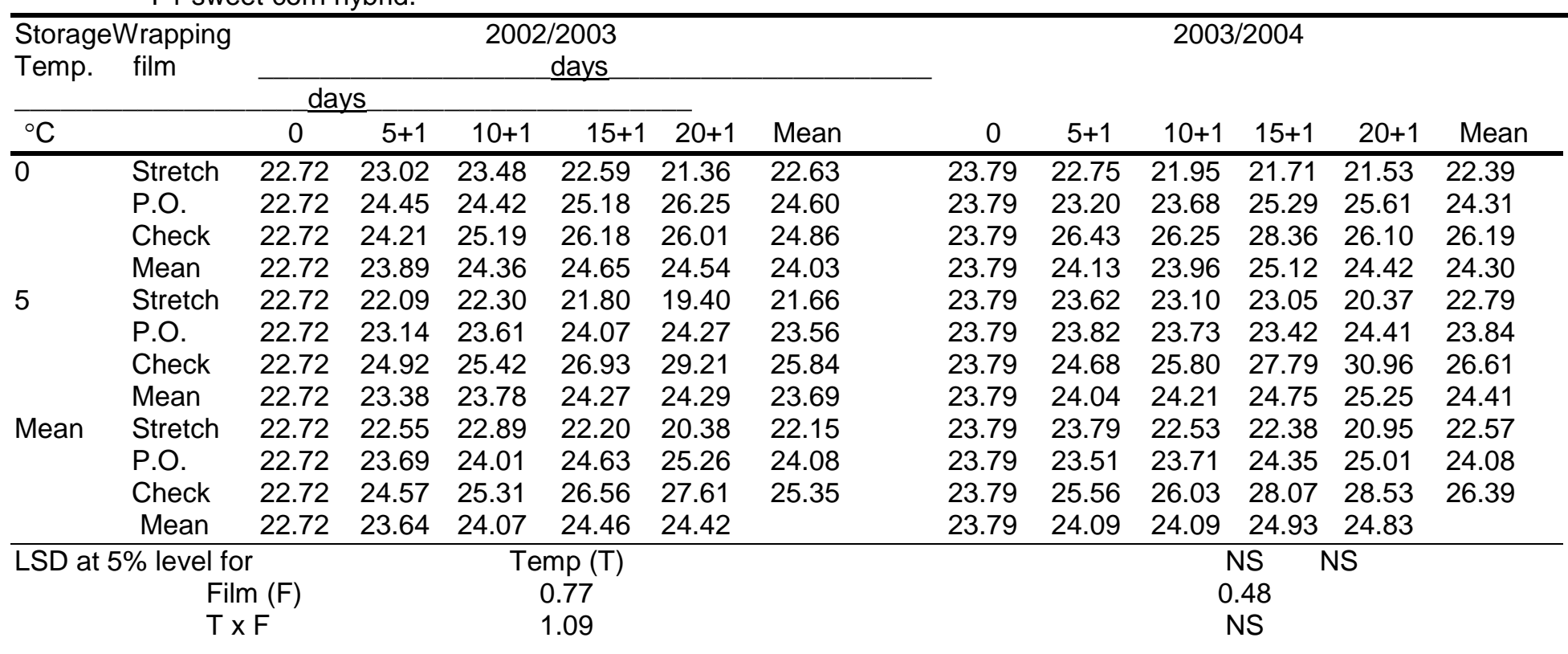

1342 
J. Agric. Sci. Mansoura Univ., 32 (2), February, 2007

$\begin{array}{ccc}\text { Storage period (S) } & 0.99 & 0.62 \\ \text { T } \times \text { S } & \text { NS } & \text { NS } \\ \text { F } \times \text { S } & 1.73 & 1.07 \\ \text { T } \times \text { F } x \text { S } & \text { NS } & 1.51 \\ \text { P.O. = polyolefin film } & & \end{array}$


Abou El-Yazied, A. et al.

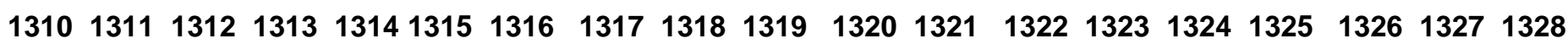

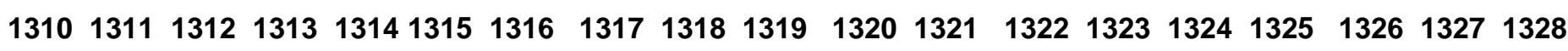

